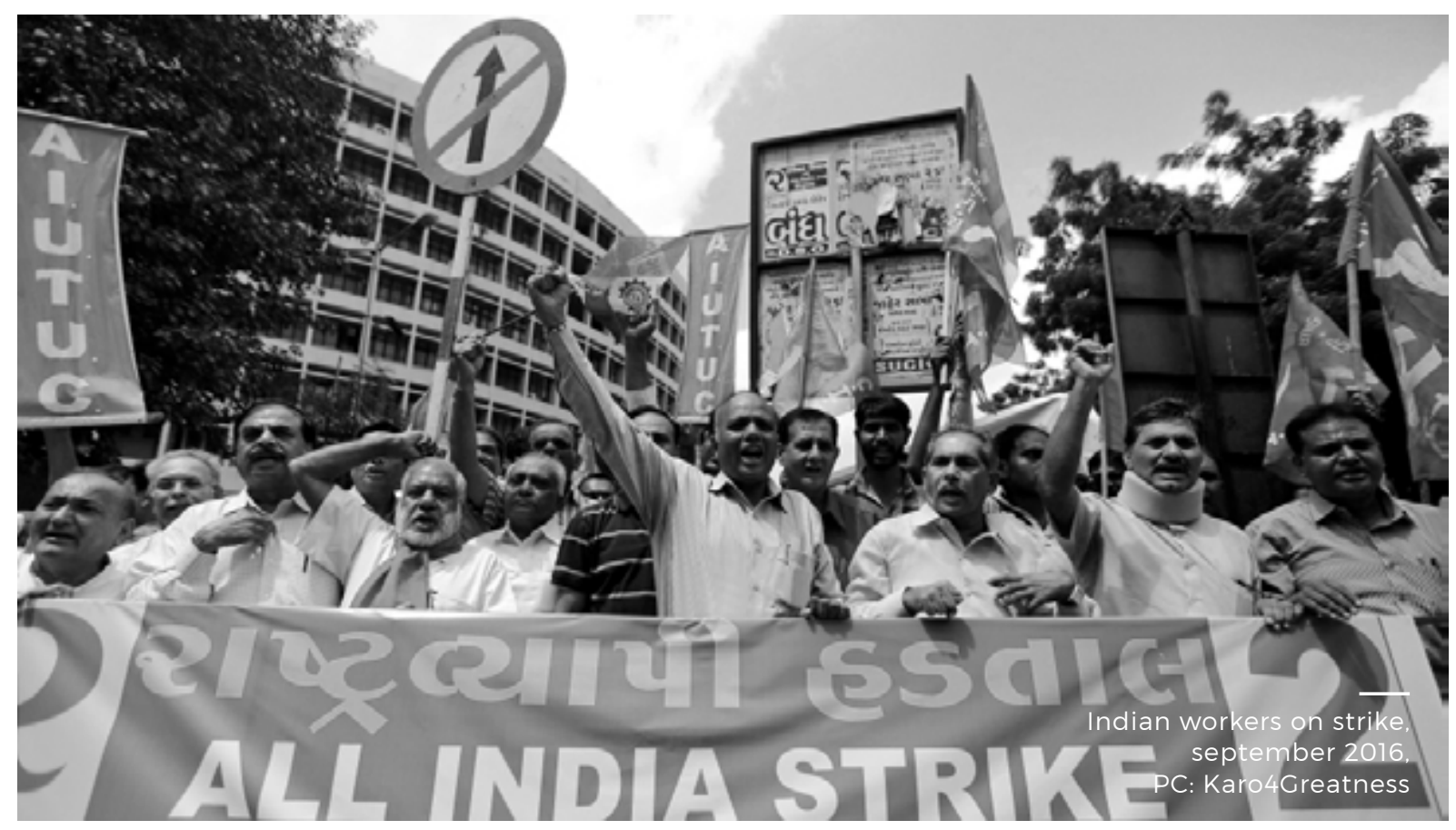

\title{
Bharat Bandh: Millions Challenge Modi's Labour Agenda
}

\section{Tom Barnes}

On 2 September 2016, possibly the largest strike in India's history-involving up to 150 million workers-caused major disruption to the country's economy. This is just the latest in a series of strikes launched by the Indian trade unions in their fight against labour law reforms promoted by the right-wing government of Narendra Modi. A significant feature of these recent struggles has been the involvement of thousands of temporary and female workers.
A massive, nationwide strikepopularised as Bharat Bandh (literally 'India closed' in Hindi/Sanskrit)-caused major disruption to India's economy on 2 September 2016. Some unions have claimed this was the largest general strike in history, with up to one hundred and fifty million workers involved and costs to business of around 2.7 billion US dollars. While these figures are probably impossible to verify, the strike was highly significant with virtually all public sector units, banks-including at least half a million bank workersand electricity power stations closed, as well as insurance companies and, in many regions, trains, bus services, and schools. Additionally, tens of thousands of coal miners joined the strike, along with university and college teachers. Many large private sector firms were also closed down or substantially affected. 
The strike reflects a clash between ten of India's largest trade union federations and the Bharatiya Janata Party (BJP)-led government of Prime Minister Narendra Modi. A right-wing populist and a member of the fascist-like Rastriya Swayamsevak Sangh (RSS), Modi was elected in a landslide victory two years ago with promises to facilitate development and higher living standards among India's majority-rural population. Part of Modi's agenda has been to reform India's system of labour laws while promoting his 'Make in India' initiative, which aims to transform India into the global destination of choice for manufacturing investment.

\section{Indian Labour in Context}

Understanding the longer-term context is helpful here. While previous governments liberalised trade, investment rules, and finance, there have been very few changes to labour laws. The core of India's employment relations system relies on laws enacted shortly after independence in 1947 . These laws have proved controversial today among policy-makers, industrialists and intellectuals. In the narrative of the political right, supported by many powerful industrialists, these laws are anachronistic and reduce 'formal sector' employment in industry, forcing millions of workers and businesses to operate informally-i.e., outside the formal system of state regulations-due to the burdensome regulations they supposedly impose on businesses.

However, in practice most of these laws are not implemented or they are relatively easy for employers to avoid. For example, the Industrial Disputes Act of 1947 formally requires businesses with one hundred or more workers to seek state government permission to close operations or sack workers. Yet many businesses have used 'voluntary

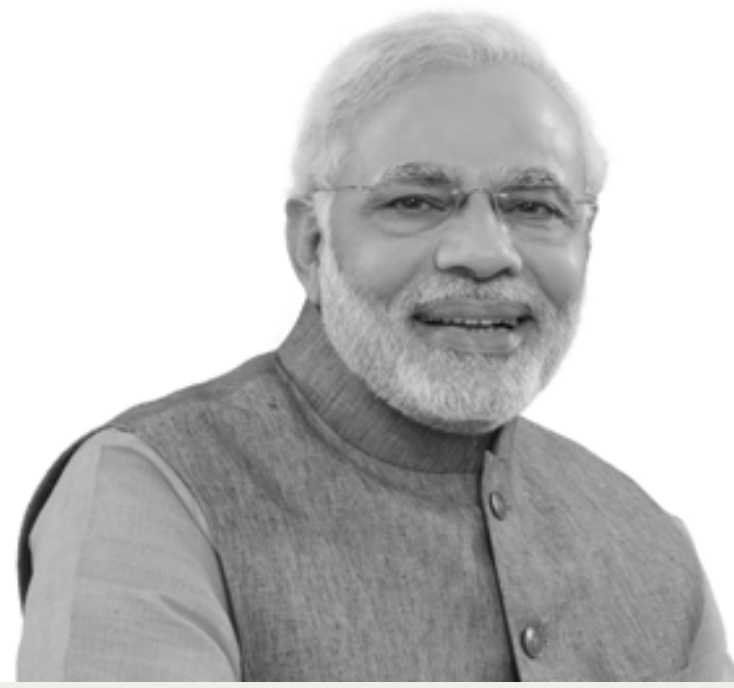

India's Prime Minister Narendra Modi, member of the right-wing Rastriya Swayamsevak Sangh, elected in 2014.

redundancy schemes' to avoid this requirement. The Contract Labour Act of 1970 limits the use of temporary or labour-hire work in medium-to-large firms. But field research in various parts of India has found that this law is routinely ignored, often via corruption between industrialists and state officials. And India has a plethora of minimum wage laws for workers in different sectors-but few of these are applied in practice and many workers are unaware they exist.

Nevertheless, the BJP has ploughed ahead with labour law reforms supposedly designed to create more formal jobs in industry and attract more foreign investment. Since its election, the Modi government has sought to consolidate changes pioneered by several BJP-led state governments by introducing two 'Labour Codes' that, they argue, simplify existing national laws. The most recent of these bills, introduced in April 2015, seeks to unify three key laws into one. The new law would lift the threshold for large firms seeking state permission for layoffs from one hundred to three hundred employees. The revised law also imposes a penalty of twenty thousand to fifty thousand rupees (approximately 
300-750 US dollars) and possible imprisonment for individual workers who participate in a strike for which two weeks advance notice has not been given-a decree previously only reserved for public sector workers. Trade unions are also angry at the bill's proposal that union office-bearers must be employed in the same industry as union members, as it contradicts the longstanding practice of workers seeking leadership from 'outsider' union federations.

\section{The Wrath of the Unions}

For the past two years, these changes have caught the ire of India's unions, which are dominated by several enormous federations-known as Central Trade Union Organisations (CTUOs). Most, though not all, CTUOs are affiliated with competing political parties, including the ruling BJP, the Indian National Congress (INC), the different Communist Parties, and other parties based on versions of nationalism, regional identity, or caste politics. The recent Bharat Bandh is the result of coordinated action by ten CTUOs who have been promoting a twelvepoint charter of demands on the Modi government. These demands include calls to expand subsidised food schemes, enforce existing labour laws including minimum wages, implement universal social security, an end to privatisation of public sector units, and a ban on foreign investment in railways and defence. The same CTUOs organised a national strike one year ago, which attracted a similar number of participants. In February 2013, tens of millions also joined a national strike. However, the BJPaffiliated union, the Bharatiya Mazdoor Sangh (BMS) pulled out of the strike after negotiations with the government. The huge numbers involved in these successive protests demonstrates both the sheer size of the Indian working class-the official labour force count is around 500 million, although the true figure is much largerand also the successful growth of many CTUOs in recent years. CTUOs claimed their total affiliated membership had grown to nearly ninety million in 2013, representing an increase of over threeand-a-half times since the last official count in 2002. Much of this success has come from organising informal workers who make up over ninety percent of all Indian workers.

This most recent general strike comes on the back of important conflicts in different industries. In March, over seventy thousand mathadi workers (head loaders), especially those employed in railways, transport and government warehouses, went on strike in Navi (New) Mumbai in response to labour law changes by the BJP and its right-wing allies in the state government of Maharashtra. In the auto industry, a strike by three thousand Honda workers in Tapukara, one hundred kilometers southwest of New Delhi was heavily repressed by the state BJP government, with over one thousand workers arrested, 136 workers fired, and dozens jailed. Five of these workers have been on a hunger strike in New Delhi for the past two weeks. This comes after the most serious conflict in the auto industry to date, at Maruti Suzuki in the nearby town of Manesar, which resulted in thousands of sackings, the tragic death of an HR manager, and 147 workers jailed, of which about a dozen were still in jail without conviction at the time of writingover four years since the dispute ended.

\section{Temporary Workers and Women on the Move}

A significant feature of these strikes was the involvement of thousands of temporary workers, very few of whom have representation or support from trade unions. Another important strike took place recently in Bengaluru (Bangalore) where up to four hundred thousand 
workers emptied the city's garments factories and flooded the streets in response to government changes to state pensions (the so-called Provident Fund). Key features of this strike included its primarily 'wildcat' character-local CTUOs were taken by surprise, despite having organised their own, much smaller response to the changes-and that the strikers were overwhelmingly women. This massive protest succeeded in deferring the Modi government's plans.

Given that women tend to work outside the male-dominated structures of most trade unions, another highly significant development occurred in the tea plantations of Munnar in Kerala in September 2015, when female plantation workers established a new women migrant-led union-Pembila Urumai ('Unity of Women' in Tamil)-to break with male-dominated unions that had virtually ignored their interests. Although Pembila Urumai was recently linked to the Aam Aaadmi Party ('Common Man')-a Delhi-centred political party based on the urbanised middle classes, which grew out of the 2011 anti-corruption movementits real significance is the leading role it reserves for women. Women's work dominates India's informal economy where it is often not even recognised as 'real' work. Other organisations-above all the Gujarat-based Self-Employment Women's Association (SEWA), which participated in the 2 September general strike-have also organised female workers in the past, including in sectors dominated by low-caste and tribal women such as brick kilns, construction sites, rag-picking, household labour, garment work or agricultural labour.

\section{New Challenges}

No doubt, many of these informal workers participated in the 2 September general strike. However, challenges remain with regard to what happens in between these set-piece events, as continued labour mobilisation is required in a society where the labour laws and social protections that have provoked such ferocious debate among industrialists, union federations, and the political classes are so rarely applied. The Modi Government has signalled its intentions to plough ahead with its controversial labour reform agenda, so points of contention leading to further future conflict are likely to emerge.

\section{Tom Barnes}

Tom is an economic sociologist at the Institute for Religion, Politics, and Society at Australian Catholic University in Melbourne. His research primarily focuses on insecure, precarious, and informal work in Australia and Asia (especially India and Indonesia). He has written a book, Informal Labour in Urban India: Three Cities, Three Journeys (Routledge, 2015) and is completing a second book on the Indian automotive industry with Cambridge University Press. 